\title{
PENGARUH PROFITABILITAS DAN GOOD CORPORATE GOVERNANCE TERHADAP PENGHINDARAN PAJAK
}

\author{
Eling Ri Kurniati ${ }^{1}$; Eky Apriani ${ }^{2}$ \\ STIE Tamansiswa Banjarnegara Jl. Mayjend Panjaitan No. 29 Banjarnegara \\ Email: elingri78@gmail.com ${ }^{1}$; aprianieky@gmail.com²
}

\begin{abstract}
The aim of this study was to examine the effect of profitability and good corporate governance toward tax avoidance. Good corporate governance was proxied by institutional ownership, an independent board of commissioners, an audit committee, and audit quality toward tax avoidance. The population in this study were mining companies listed on the Indonesia Stock Exchange in the 2014-2018 period with amount 47 companies. Samples were selected using the purposive sampling method. The total sample used in this study are 9 mining companies with a study period of 5 years, so that the samples obtained were 45 samples. The analytical method used in this study is multiple linear regression analysis. The results of this study indicate that profitability have a significant effect toward tax avoidance, while the institutional ownership, independent board of commissioners, audit committee, and audit quality are unable to establish the influence toward tax avoidance.

Keywords: profitability, good corporate governance, institutional ownership, independent board of commissioners, audit committee, audit quality, and tax avoidance.
\end{abstract}

\section{PENDAHULUAN}

\section{Latar Belakang}

Pajak menurut sisi akuntansi merupakan biaya atau beban yang akan mengurangi laba bersih, hal ini bertolakbelakang dengan tujuan semua entitas bisnis yang ingin mempunyai laba besar. Faktor tersebut yang menjadikan pajak sebagai beban yang dapat memicu terjadinya peminimalisiran terhadap pembayaran pajak perusahaan. Usaha meminimalkan beban pajak dapat dilakukan secara legal maupun ilegal. Upaya pengurangan pajak secara legal disebut penghindaran pajak sedangkan upaya pengurangan pajak secara ilegal disebut penggelapan pajak.

Terdapat banyak kasus terkait penghindaran pajak yang umumnya

Vol. 12, No. 1, Januari 2021, Halaman 55-68 dilakukan oleh perusahaan besar secara global. Belakangan ini banyak ditemukan praktik penghindaran pajak oleh perusahaan besar dunia seperti Google, Apple, Starbucks, Ikea, Amazon, Gap, dan Microsoft. Tidak hanya perusahaan besar dunia, di Indonesia pun terdapat kasus dari penghindaran pajak. Dilansir dari CNBC Indonesia Fenomena terbaru mengenai penghindaran pajak pada sektor pertambangan di Indonesia yang dilakukan oleh PT. Adaro Energy Tbk. Dalam laporan yang dirilis berjudul Taxing Times for Adaro, Global Witness mengungkapkan bahwa dari 2009-2017 Adaro dengan skema transfer pricing memanfaatkan anak perusahaannya di Singapura, Coaltrade Services International, membayar US\$ 125 
juta lebih sedikit dari yang seharusnya disetorkan ke pemerintah Indonesia.

Dari kasus diatas dapat diketahui bahwa penyebab penghindaran pajak yang dilakukan perusahaan berhubungan dengan profitabilitas karena profitabilitas tersebut merupakan salah satu pengukuran bagi kinerja suatu perusahaan. Menurut Maharani dan Suardana (2014) Profitabilitas menggambarkan kemampuan suatu perusahaan dalam menghasilkan laba selama periode tertentu pada tingkat penjualan, asset dan modal saham. Hasil penelitian dari Komang, Putu, dan I Nyoman (2016) mengatakan bahwa ROA berpengaruh positif terhadap penghindaran pajak, sedangkan menurut Deddy, Rita, dan Kharis (2016) mengatakan bahwa profitabilitas tidak berpengaruh terhadap penghindaran pajak.

Selain profitabilitas, good corporate governance juga dapat mempengaruhi praktik penghindaran pajak. Penerapan corporate governance yang pertama yaitu kepemilikan institusional. Dengan adanya kepemilikan institusional maka akan ada kontrol yang lebih baik. Menurut Utami (2013) perusahaan yang memiliki kepemilikan institusional yang tinggi akan semakin agresif dalam meminimalisir pelaporan perpajakannya.

Dewan Komisaris independen merupakan orang yang tidak terafiliasi dalam segala hal dengan pemegang saham pengendali, tidak memiliki hubungan afiliasi dengan direksi serta tidak menjabat sebagai direktur pada suatu perusahaan yang terkait dengan perusahaan pemilik. Jumlah Komisaris Independen wajib paling kurang 30\% (tiga puluh persen) dari jumlah

Vol. 12, No. 1, Januari 2021, Halaman 55-68 seluruh anggota dewan komisaris. Apabila presentase komisaris independen diatas $30 \%$ maka merupakan indikator bahwa pelaksanaan corporate governance telah berjalan dengan baik sehingga mampu mengontrol dan mengendalikan keinginan pihak manajemen perusahaan untuk melakukan penghematan pajak sehingga akan menurunkan praktik penghindaran pajak (Annisa dan Kurniasih, 2012).

Fenny (2014) menyebutkan komite audit adalah sekumpulan orang yang dipilih dari anggota dewan komisaris yang bertanggung jawab untuk mengawasi proses pelaporan keuangan dan pengungkapan. Komite audit memiliki peran penting sebagai salah satu organ perusahaan yang mutlak harus ada dalam penerapan Corporate Governance.

Kualitas audit adalah segala kemungkinan yang dapat terjadi saat auditor mengaudit laporan keuangan dan menemukan kesalahan kemudian melaporkannya dalam laporan keuangan auditan (Dewi dan Jati, 2014). Laporan keuangan yang diaudit oleh auditor KAP (Kantor Akuntan Publik) The Big Four (Price Water House Cooper - PWC, Deloitte Touche Tohmatsu, KPMG, Ernst \& Young $-E \& Y$ ) menurut beberapa referensi lebih berkualitas karena memiliki tingkat kecurangan yang lebih rendah dibandingkan dengan perusahaan yang diaudit KAP Non The Big Four (Annisa dan Kurniasih, 2012). Menurut Chai dan Liu dalam Annisa dan Kurniasih (2012), jika nominal pajak yang dibayar telalu tinggi biasanya akan memaksa perusahaan untuk melakukan penggelapan pajak, maka semakin berkualitas audit suatu perusahaan, maka 56

Copyright@2021, MEDIKONIS 
perusahaan tersebut cenderung tidak melakukan manipulasi laba untuk kepentingan perpajakan.

Beberapa penelitian terkait bagaimana pengaruh corporate governance terhadap penghindaran pajak, yaitu Komang et al. (2016). Hasil penelitiannya menunjukkan bahwa profitabilitas berpengaruh positif terhadap penghindaran pajak. Kepemilikan institusional dan dewan komisaris independen sebagai proksi dari Good Corporate Governance juga menunjukan pengaruh positif terhadap penghindaran pajak, namun pada penelitian Deddy Dyas et al. (2017) menunjukkan bahwa tata kelola perusahaan atau Good Corporate Governance tidak berpengaruh pada penghindaran pajak.

Berdasar uraian diatas, maka peneliti melakukan penelitian untuk menguji pengaruh Profitabilitas dan Good Corporate Governance terhadap Penghindaran Pajak pada perusahaan pertambangan yang terdaftar di Bursa Efek Indonesia periode 2014-2018.

\section{Rumusan Masalah}

1. Apakah profitabilitas berpengaruh terhadap penghindaran pajak?

2. Apakah kepemilikan institusional berpengaruh terhadap penghindaran pajak?

3. Apakah dewan komisaris independen berpengaruh terhadap penghindaran pajak?

4. Apakah komite audit berpengaruh terhadap penghindaran pajak?

5. Apakah kualitas audit berpengaruh terhadap penghindaran pajak?

6. Apakah profitabilitas, kepemilikan institusional, dewan komisaris independen, komite audit, dan kualitas audit

Vol. 12, No. 1, Januari 2021, Halaman 55-68 berpengaruh secara simultan terhadap penghindaran pajak?

\section{METODE PENELITIAN}

\section{Lokasi Penelitian}

Penelitian ini dilakukan pada perusahaan pertambangan yang terdaftar di Bursa Efek Indonesia melalui website www.idx.co.id.

\section{Jenis Penelitian}

Penelitian ini menggunakan data kuantitatif.

\section{Variable Penelitian}

a.Variabel independen : Profitabilitas (X1), Kepemilikan Institusional (X2), Dewan Komisaris Independen (X3), Komite Audit (X4), Kualitas Audit (X5)

b.Variabel dependen : Penghindaran $\operatorname{Pajak}(\mathrm{Y})$

\section{Definisi Konsep dan Definisi Operasional Variabel}

a. Profitabilitas

Definisi Konsep : Suatu ukuran dalam presentase yang digunakan untuk menilai sejauh mana perusahaan mampu menghasilkan laba pada tingkat yang dapat diterima.

Definisi Operasional : Kemampuan perusahaan memperoleh laba dalam hubungannya dengan penjualan, total aktiva maupun modal sendiri.

Indikator : Retturn On Assets $=\frac{\text { Laba Bersih }}{\text { Total Aset }}$

b. Kepemilikan Institusional

Definisi Konsep : Kepemilikan jumlah saham perusahaan oleh lembaga keuangan non bank dimana lembaga tersebut mengelola dana atas nama orang lain. 
Definisi Operasional : Proporsi saham yang dimiliki oleh pihak institusi pada akhir tahun yang diukur dalam presentase.

Indikator :

Kepemilikan Institusional $=\frac{\begin{array}{c}\text { Total Saham } \\ \text { Milik Institusi }\end{array}}{\begin{array}{c}\text { Total Saham } \\ \text { Beredar }\end{array}}$

c. Dewan Komisaris Independen

Definisi Konsep : Anggota dewan komisaris yang tidak terafiliasi dengan Direksi, anggota dewan komisaris lainnya dan pemegang saham pengendali, serta bebas dari hubungan bisnis atau hubunggan lainnya yang dapat mempengaruhi kemampuannya untuk bertindak independen atau bertindak semata-mata demi kepentingan perusahaan.

Definisi Operasional : Pihak yang tidak memiliki hubungan dengan anggota dewan yang lainnya. Dewan komisaris independen dapat diukur menggunakan indikator jumlah anggota komisaris independen yang berasal dari luar bank terhadap seluruh anggota dewan komisaris.

Indikator : Dewan Komisaris Independen= Jumlah DKI

Jumlah

Dewan

Komisaris

DKI: Dewan Komisaris Indpenden

d. Komite Audit

Definisi Konsep : Komite yang dibentuk oleh dan bertanggung jawab kepada Dewan Komisaris dalam membantu melaksanakan tugas dan fungsi pengawasan Dewan Komisaris.

Definisi Operasional : Komite audit terdiri dari sekurang-kurangnya tiga orang, yang diketuai oleh komisaris independen perusahaan dengan dua orang eksternal yang independen.
Indikator : Komite Audit $=\frac{\begin{array}{c}\text { Total komite audit } \\ \text { luar perusahaan }\end{array}}{\begin{array}{c}\text { Total anggota } \\ \text { komite audit }\end{array}}$

e. Kualitas Audit

Definisi Konsep : Hasil audit berdasar standar auditing dan standar pengendalian mutu yang menjadi ukuran pelaksanaan tugas dan tanggung jawab profesi auditor.

Definisi Operasional: Kualitas audit yaitu kemungkinan bahwa auditor akan menemukan dan melaporkan pelanggaran dalam sistem akutansi. Diukur dengan KAP Big Four dan non big four.

Indikator : Kualitas audit $=$ Bernilai 1 apabila diaudit KAP Big Four. Bernilai 0 apabila diaudit KAP Non Big Four.

\section{f. Penghindaran Pajak}

Definisi Konsep : Usaha untuk mengurangi beban pajak sesuai dengan undang-undang. Definisi Operasional: Penghindaran pajak diukur menggunakan CETR yaitu dengan membagi kas yang dikeluarkan untuk biaya pajak dibagi dengan laba sebelum pajak.

Indikator : $\mathrm{CETR}=\frac{\text { Pembayaran Pajak }}{\text { Laba Sebelum Pajak }}$

\section{Populasi Sampel dan Teknik Sampling}

a. Populasi Penelitian

Populasi dalam penelitian ini adalah 47 perusahaan pertambangan yang terdaftar di BEI periode 2014-2018.

b. Teknik Sampling

Teknik sampling yang digunakan dalam penelitian yaitu purposive sampling. Adapun kriteria yang digunakan :

\begin{tabular}{|c|l|c|}
\hline No & \multicolumn{1}{|c|}{ Keterangan } & Jumlah \\
\hline 1 & $\begin{array}{l}\text { Perusahaan pertambangan yang terdaftar di } \\
\text { BEI periode 2014-2018 }\end{array}$ & 47 \\
\hline 2 & $\begin{array}{l}\text { Perusahaan pertambangan yang delisting dari } \\
\text { BEI periode 2014-2018 }\end{array}$ & 3 \\
\hline 3 & $\begin{array}{l}\text { Perusahaan yang tidak melaporkan laporan } \\
\text { keuangan pada 2014-2018 }\end{array}$ & 5 \\
\hline
\end{tabular}




\begin{tabular}{|c|l|c|}
\hline 4 & $\begin{array}{l}\text { Perusahaan yang mengalami kerugian selama } \\
\text { periode 2014-2018 }\end{array}$ & 23 \\
\hline 5 & Analisis data perusahaan yang tidak normal & 7 \\
\hline 6 & $\begin{array}{l}\text { Perusahaan yang datanya lengkap dan dapat } \\
\text { dijadikan sebagai sampel }\end{array}$ & 9 \\
\hline \multicolumn{2}{|l}{ Jumlah Observasi 2014-2018 (x5) } & $\mathbf{4 5}$ \\
\hline
\end{tabular}

c. Sampel Penelitian

Sampel penelitian sebanyak 9 perusahaan pertambangan yang terdaftar di BEI selama 5 tahun, jadi sampel akhir yang digunakan sebanyak 45 sampel.

\section{Teknik Analisis Data}

Adapun teknik analisis data yang digunakan dalam penelitian ini adalah :

a. Uji asumsi klasik, terdiri dari :

1. Uji Normalitas

Uji normalitas bertujuan untuk menguji apakah dalam model regresi memiliki distribusi normal. Penelitian ini menggunakan uji Kolmogorov-Smirnov. Apabila nilai signifikan $>0,05$ maka residual berdistribusi normal.

2. Uji Multikolinieritas

Uji multikolinieritas bertujuan untuk menguji apakah pada model regresi ditemukan adanya korelasi antar variabel independen, jika terjadi korelasi maka dikatakan telah terjadi multikolinieritas. Model regresi yang baik tidak terjadi gejala multikolinieritas. Tidak terjadi multikolinieritas apabila nilai tolerance > 0,10 dan VIF $<10$.

\section{Uji Heterokedaktisitas}

Uji heterokedaktisitas dilakukan untuk melihat apakah terdapat ketidaksamaan varian dari residual satu pengamatan ke pengamatan lain. Model regresi yang baik adalah yang terdapat persamaan varians dari pengamatan satu ke pengamatan lain atau disebut homokedaktisitas. Pada penelitian ini, cara yang digunakan untuk menguji gejala heterokedaktisitas menggunakan uji glejser, jika nilai Signya lebih besar dari nilai alpha (Sig. $>\alpha$ ), maka model regresi tidak mengandung gejala heteroskedastisitas.

4. Uji Autokorelasi

Autokorelasi bertujuan untuk menguji apakah model regresi terjadi korelasi diantara anggota sampel penelitian yang diurutkan berdasar waktu sebelumnya. Persamaan regresi yang baik adalah yang tidak terjadi gejala autokorelasi. Diukur dengan uji Durbin Watson (DW). Dikatakan tidak ada autokorelasi bila nilai $\mathrm{dl}\langle\mathrm{DW}\rangle$ du dan $\mathrm{dl}<(4-\mathrm{DW})\rangle \mathrm{du}$.

\section{b. Analisis regresi linear berganda}

Regresi berganda digunakan untuk menjawab rumusan masalah yaitu menguji apakah profitabilitas dan mekanisme good corporate governance yang diproksikan dengan kepemilikan institusional, dewan komisaris imdependen, komite audit, dan kualitas audit berpengaruh terhadap tindakan penghindaran pajak. Model regresi yang digunakan untuk menguji hipotesis yang dirumuskan sebagai berikut:

$Y=\alpha+\beta 1 \mathrm{X} 1+\beta 2 \mathrm{X} 2+\beta 3 \mathrm{X} 3+\beta 4 \mathrm{X} 4+\beta 5 \mathrm{X} 5+\varepsilon$

Dengan : $\mathrm{Y}=$ Penghindaran Pajak, $\alpha=$ Konstanta, $\mathrm{X} 1=$ Profitabilitas, $\mathrm{X} 2=$ Kepemilikan Institusional, X3 = Dewan Komisaris Independen, X4 = Komite Audit, X5 = Kualitas Auditor, $\beta 1-\beta 5=$ Koefisien Regresi variabel X1, X2, X3, X4, dan X5, lalu $\varepsilon=$ error.

c. Uji Hipotesis, terdiri dari :

1. Uji Siginifikansi Parsial (Uji T)

Uji statistik $\mathrm{t}$ digunakan untuk mengetahui seberapa jauh pengaruh satu 
variabel independen secara parsial dalam menerangkan variabel dependen. Kriteria dalam pengujian ini yaitu apabila nilai sig < 0,05 dan nilai $\mathrm{T}$ hitung $>\mathrm{T}$ tabel maka hipotesis diterima.

2. Uji Siginifikansi Simultan (Uji F)

Uji statistik $F$ digunakan untuk mengetahui apakah variabel-variabel independen mempunyai pengaruh secara simultan terhadap variabel dependen. Kriteria dalam pengujian ini yaitu apabila nilai sig < 0,05 dan nilai $\mathrm{F}$ hitung $>\mathrm{F}$ tabel maka hipotesis diterima.

3. Uji Koefisien Determinasi $\left(\mathrm{R}^{2}\right)$

\section{Koefisien Determinasi}

$\left(\mathrm{R}^{2}\right)$

mengukur seberapa jauh keampuan model dalam menerangkan variasi variabel dependen. Nilai koefisien determinasi adalah antara nol dan satu. Nilai yang mendekati satu berarti variabel-variabel independen memberikan hampir semua informasi yang dibutuhkan untuk memprediksi variasi variabel dependen (Ghozali, 2016).

\section{HASIL DAN PEMBAHASAN}

a.Hasil uji asumsi klasik

\section{Uji Normalitas}

\begin{tabular}{|l|r|}
\hline & Standardized Residual \\
\hline$N$ & 45 \\
\hline Asymp. Sig. (2-tailed) & $200^{\mathrm{c}, \mathrm{d}}$ \\
\hline
\end{tabular}

Dari tabel Kolmogorov-Smirnov test nilai Asymp. Sig. (2-tailed) sebesar 0,200 > 0,05 (Sig. $>\alpha$ ). Hal ini berarti nilai residual terstandarisasi dinyatakan menyebar secara normal.

\section{Uji Multikolinieritas}

\begin{tabular}{|l|r|c|}
\hline \multirow{2}{*}{ Model } & \multicolumn{2}{|c|}{ Collinearity Statistics } \\
\cline { 2 - 3 } & Tolerance & VIF \\
\hline Profitabilitas &, 679 & 1,472 \\
\hline
\end{tabular}

Vol. 12, No. 1, Januari 2021, Halaman 55-68

\begin{tabular}{|l|r|r|}
\hline $\begin{array}{l}\text { Kepemilikan } \\
\text { Institusional }\end{array}$ &, 689 & 1,452 \\
\hline $\begin{array}{l}\text { Dewan Komisaris } \\
\text { Independen }\end{array}$ &, 943 & 1,060 \\
\hline Komite Audit &, 923 & 1,083 \\
\hline Kualitas Audit &, 907 & 1,103 \\
\hline \multicolumn{1}{|c|}{ Dari tabel diatas } & masing-masing \\
\hline
\end{tabular}
variable memiliki nilai tolerance $>0,10$ dan nilai VIF < 10, maka dapat disimpulkan pada model regresi yang tidak terjadi gejala multikolinieritas.

\section{Uji Heterokedaktisitas}

\begin{tabular}{|l|r|c|}
\hline \multicolumn{1}{|c|}{ Model } & \multicolumn{1}{c|}{$\mathrm{T}$} & Sig. \\
\hline Profitabilitas & $-1,157$ &, 254 \\
\hline Kepemilikan Institusional &, 414 &, 681 \\
\hline Dewan Komisaris Independen &, 202 &, 841 \\
\hline Komite Audit &, 103 &, 919 \\
\hline Kualitas Audit &, 250 &, 750 \\
\hline \multicolumn{2}{|c|}{ Dari tabel diatas masing-masing }
\end{tabular}
variable memiliki nilai signifikansi $>0,05$ sehingga dapat disimpulkan bahwa model regresi tidak terjadi gejala heterokedaktisitas.

\section{Uji Autokorelasi}

\begin{tabular}{|l|c|r|r|}
\hline Model & R & R Square & Durbin-Watson \\
\hline 1 &, $493^{\mathrm{a}}$ &, 243 & 2,488 \\
\hline
\end{tabular}

Dari tabel diatas nilai DW sebesar 2,488 dan pada tabel DW diperoleh nilai 4dl dan 4-du sebesar 2,7126 dan 2,2238. Berdasar ketentuan autokorelasi maka disimpulkan bahwa tidak terdapat autokorelasi $(\mathrm{dl}<\mathrm{DW}>\mathrm{du})$.

\section{b. Analisis Regresi Linear Berganda}

\begin{tabular}{|l|r|r|}
\hline \multirow{2}{*}{ Model } & \multicolumn{2}{|c|}{$\begin{array}{c}\text { Unstandardized } \\
\text { Coefficients }\end{array}$} \\
\cline { 2 - 3 } & \multicolumn{1}{|c|}{ B } & Std. Error \\
\hline Profitabilitas &,- 527 &, 247 \\
\hline Kepemilikan Institusional &,- 107 &, 117 \\
\hline Dewan Komisaris &, 003 &, 185 \\
Independen & &, 319 \\
\hline Komite Audit &, 338 &, \\
\hline
\end{tabular}


Kualitas Audit

$-, 004$

, 043

Persamaan regresi dapat disusun berdasarkan nilai koefisien yang dapat dilihat pada kolom B (Unstandardized Coefficients) sehingga terbentuk persamaan regresi linier sebagai berikut:

$\mathrm{Y}=\mathrm{a}+\beta 1 \mathrm{X} 1-\beta 2 \mathrm{X} 2-\beta 3 \mathrm{X} 3+\beta 4 \mathrm{X} 4+$
$\beta 5 \mathrm{X} 5$
$\mathrm{Y}=0,291-0,527 \mathrm{X} 1-0,107 \mathrm{X} 2+0,003 \mathrm{X} 3$
$+0,338 \mathrm{X} 4-0,004 \mathrm{X} 5$

Dari persamaan di atas dapat disimpulkan pengaruh antara profitabilitas (X1), kepemilikan institusional (X2), dewan komisaris independen (X3), komite audit (X4), dan kualitas audit (X5) terhadap penghindaran pajak (Y), yaitu:

a. Konstanta sebesar 0,291, artinya jika variabel profitabilitas (X1), kepemilikan institusional (X2), dewan komisaris independen (X3), komite audit (X4), dan kualitas audit (X5) terhadap penghindaran pajak (Y) nilainya adalah 0,291.

b. Koefisien regresi variabel profitabilitas (X1) sebesar -0,527, artinya jika variabel bebas lainnya nilainya tetap dan profitabilitas mengalami kenaikan $1 \%$, maka penghindaran pajak (Y) akan mengalami penurunan sebesar 0,527. Koefisien bernilai negatif artinya terjadi hubungan negatif antara profitabilitas dengan penghindaran pajak, semakin naik angka profitabilitas maka semakin menurun praktik dari penghindaran pajak pada perusahaan tersebut.

c. Koefisien regresi variabel kepemilikan institusional (X2) sebesar -0,107. Artinya jika variabel bebas lainnya nilainya tetap dan kepemilikan institusional mengalami kenaikan $1 \%$, maka penghindaran pajak (Y)

Vol. 12, No. 1, Januari 2021, Halaman 55-68 akan mengalami penurunan sebesar 0,107. Koefisien bernilai negatif artinya terjadi hubungan negatif antara kepemilikan institusional dengan penghindaran pajak, semakin naik angka kepemilikan institusional maka semakin menurun praktik penghindaran pajak pada perusahaan tersebut.

d. Koefisien regresi variabel dewan komisaris independen (X3) sebesar 0,003. Artinya jika variabel bebas lainnya nilainya tetap dan persentase dewan komisaris independen mengalami kenaikan $1 \%$, maka penghindaran pajak (Y) akan mengalami penurunan sebesar 0,003 . Koefisien bernilai positif artinya terjadi hubungan positif antara dewan komisaris independen dengan penghindaran pajak, semakin naik angka persentase dewan komisaris independen maka semakin rendah praktik dari penghindaran pajak pada perusahaan tersebut.

e. Koefisien regresi variabel jumlah komite audit (X4) sebesar 0,338. artinya jika variabel bebas lainnya nilainya tetap dan komite audit mengalami kenaikan 1\%, maka penghindaran pajak (Y) akan mengalami kenaikan sebesar 0,338. Koefisien bernilai positif artinya terjadi hubungan positif antara komite audit dengan penghindaran pajak, semakin naik angka jumlah komite audit (X4) maka akan semakin naik penghindaran pajak pada perusahaan tersebut.

f. Koefisien regresi variabel kualitas audit (X5) sebesar -0,04. Artinya jika variabel bebas lainnya nilainya tetap dan kualitas audit mengalami kenaikan 1\%, maka penghindaran pajak (Y) akan mengalami kenaikan sebesar 0,04. Koefisien bernilai 
negatif artinya terjadi hubungan negatif antara kualitas audit dengan penghindaran pajak, semakin naik angka jumlah kualitas audit (X4) maka semakin naik penghindaran pajak pada perusahaan tersebut.

\section{c. Uji Hipotesis}

\section{Uji Signifikansi Parsial (Uji T)}

\begin{tabular}{|l|r|r|}
\hline \multicolumn{1}{|c|}{ Model } & \multicolumn{1}{c|}{ T } & \multicolumn{1}{c|}{ Sig } \\
\hline Profitabilitas & $-2,132$ &, 039 \\
\hline Kepemilikan Institusional &,- 910 &, 369 \\
\hline Dewan Komisaris Independen &, 014 &, 989 \\
\hline Komite Audit & 1,057 &, 292 \\
\hline Kualitas Audit &,- 085 &, 933 \\
\hline
\end{tabular}

Pengaruh profitabilitas terhadap penghindaran pajak

Berdasarkan tabel diatas, Profitabilitas secara statistik menunjukkan nilai sig. lebih kecil dari $\alpha(0,039<0,05)$ dan memiliki $\mathrm{t}$ hitung lebih besar dari t tabel (2,132> 2,02269). Nilai koefisien regresi sebesar 0,527. Dapat disimpulkan bahwa:

H1 : Profitabilitas berpengaruh negatif dan signifikan terhadap penghindaran pajak.

Pengaruh kepemilikan institusional terhadap penghindaran pajak

Kepemilikan institusional secara statistik menunjukkan nilai sig. lebih besar dari $\alpha$ $(0,369<0,05)$ dan memiliki t hitung lebih kecil dari t tabel $(0,910>2,02269)$. Nilai koefisien regresi sebesar $-0,107$. Dapat disimpulkan bahwa:

H2 : Kepemilikan institusional tidak berpengaruh signifikan terhadap penghindaran pajak.

Pengaruh dewan komisaris independen terhadap penghindaran pajak

Dewan komisaris independen secara statistik menunjukkan nilai sig. lebih besar dari $\alpha(0,989>0,05)$ dan memiliki t hitung lebih kecil dari t tabel $(0,014<2,02269)$.

Vol. 12, No. 1, Januari 2021, Halaman 55-68
Nilai koefisien regresi sebesar 0,003. Dapat disimpulkan bahwa:

H3 : Dewan komisaris independen tidak berpengaruh signifikan terhadap penghindaran pajak.

Pengaruh komite audit terhadap penghindaran pajak

Komite audit menunjukkan nilai sig. lebih besar dari $\alpha(0,292>0,05)$ dan memiliki $t$ hitung lebih kecil dari t tabel $(1,057<$ 2,02269). Nilai koefisien regresi sebesar 0,338. Dapat disimpulkan bahwa:

H4 : Komite audit tidak berpengaruh signifikan terhadap penghindaran pajak.

Pengaruh kualitas audit terhadap penghindaran pajak

Kualitas audit secara statistik menunjukkan nilai sig. lebih besar dari $\alpha(0,933>0,05)$ dan memiliki thitung lebih kecil dari t tabel $(0,085<2,02269)$. nilai koefisien regresi sebesar -0,004. Dapat disimpulkan bahwa: H5 : Kualitas audit tidak berpengaruh signifikan terhadap penghindaran pajak.

b. Uji Signifikansi Simultan (Uji F)

\begin{tabular}{|l|c|c|}
\hline Model & F & Sig. \\
\hline Regression & 2,505 &, $046^{\mathrm{b}}$ \\
\hline Residual & & \\
\hline Total & & \\
\hline
\end{tabular}

Pengaruh profitabilitas, kepemilikan institusional, dewan komisaris independen, komite audit, dan kualias audit terhadap penghindaran pajak.

Berdasarkan tabel diatas, nilai $\mathrm{F}$ hitung sebesar 2,505 dengan Sig. 0,046. Nilai signifikansi $<0,05(0,046<0,05)$. Menunjukkan bahwa profitabilitas, kepemilikan institusional, dewan komisaris independen, komite audit dan kualitas audit secara simultan berpengaruh signifikan terhadap penghindaran pajak. 
H6 : Profitabilitas, kepemilikan institusional, dewan komisaris independen, komite audit, dan kualias audit berpengaruh signifikan terhadap penghindaran pajak.

\section{Uji Koefisien Determinasi}

\begin{tabular}{|l|l|r|r|}
\hline Model & $\mathrm{R}$ & R Square & Durbin-Watson \\
\hline 1 &, $493^{\mathrm{a}}$ &, 243 & 2,488 \\
\hline
\end{tabular}

Berdasarkan tabel diatas, nilai $R$

Square sebesar 0,243. Menunjukkan bahwa pengaruh profitabilitas, kepemilikan institusional, dewan komisaris independen, komite audit dan kuaitas audit terhadap penghindaran pajak adalah 24,3\%, sedangkan sisanya sebesar $75,7 \%$ dipengaruhi oleh variabel-variabel lain yang tidak dimasukkan dalam penelitian ini.

\section{PEMBAHASAN}

\section{Pengaruh Profitabilitas terhadap} Penghindaran Pajak

Kurniasih dan
menyakatan bahi (2010) merupakan cerminan tingkat pertumbuhan keuangan terkait dengan perolehan laba perusahaan. Profitabilitas dapat diukur menggunakan rasio return on asset (ROA). Nilai ROA yang tinggi, menandakan tingginya tingkat laba yang dihasilkan oleh perusahaan serta menandakan tingginya tingkat profitabilitas pada perusahaan tersebut.

$\begin{array}{rrr}\text { Hasil pada } & \text { penelitian ini } \\ \text { menunjukan } & \text { bahwa } & \text { profitabilitas }\end{array}$ berpengaruh negatif dan signifikan terhadap penghindaran pajak. Sejalan dengan penelitian Rizal (2016) dan Zarai (2013). Hasil yang negatif menunjukan bahwa semakin tingginya profitabilitas yang dihasilkan akan berdampak pada peningkatan tarif pajak perusahaan.

Vol. 12, No. 1, Januari 2021, Halaman 55-68
Perusahaan yang laba atau profitnya tinggi cenderung akan melakukan perencanaan pajak atau tax planning. Perusahaan yang memiliki perencanaan pajak yang baik akan memperoleh pajak yang optimal, maka kecenderungan perusahaan untuk melakukan penghindaran pajak akan menurun.

Dapat disimpulkan bahwa penghindaran pajak yang dilakukan perusahaan berhubungan dengan profitabilitas yang dihasilkan karena profitabilitas menggambarkan kemampuan suatu perusahaan dalam menghasilkan laba. Semakin tinggi profit atau keuntungan yang dihasilkkan perusahaan akan berdampak pada tinnginya tarif pajak perusahaan, maka perusahaan akan cenderung untuk melakukan perencanaan pajak, semakin baik perencanaannya maka perolehan pajaknya pun akan lebih optimal, sehingga mengurangi praktik penghindaran pajak.

\section{Pengaruh Kepemilikan Institusional terhadap Penghindaran Pajak}

Kepemilikan institusional sebagai pengawas yang berasal dari luar perusahaan memegang peranan yang penting dalam memonitor manajemen, karena dengan adanya kepemilikan institusional akan mendorong pengawasan yang lebih optimal terhadap manajemen perusahaan agar dalam menghasilkan laba berdasarkan aturan yang berlaku, karena pada dasarnya investor institusional lebih melihat seberapa jauh manajemen taat kepada aturan dalam menghasilkan laba untuk perusahaan. Dengan demikian investor institusional mempunyai andil dalam penetapan kebijakan yang terkait dengan tindakan penghindaran pajak (Fadhilah, 2014). 
Hasil pada penelitian ini menunjukan bahwa kepemilikan institusional tidak membuktikan adanya pengaruh yang signifikan terhadap penghindaran pajak. Sejalan dengan penelitian Fenny Winata (2014) dan Rizal (2016). Hasil yang menunjukkan bahwa kepemilikan institusional yang tidak berpengaruh signifikan terhadap penghindaran pajak memiliki arti besar kecilnya kepemilikan institusional tidak membuat praktik penghindaran pajak yang dilakukan oleh perusahaan tersebut dapat dihindari.

Adanya kepemilikan institusional diharapkan dapat mengurangi praktik penghindaran pajak, namun terdapat alasan yang menyebabkan kepemilikan institusional tidak berpengaruh terhadap penghindaran pajak, yaitu karena kepemilikan institusional mempercayakan pengawasan dan pengelolaan perusahaan terhadap dewan komisaris karena itu merupakan tugas mereka, sehingga ada atau tidaknya kepemilikan institusional penghindaran pajak akan tetap terjadi.

\section{Pengaruh Dewan Komisaris Independen terhadap Penghindaran Pajak}

Annisa (2012) mengatakan bahwa komisaris independen merupakan pihak yang tidak terafiliasi dengan pemegang saham pengendali, anggota direksi dan dewan komisaris lain. Kehadiran dewan komisaris dapat meningkatkan pengawasan terhadap kinerja direksi dimana dengan semakin banyaknya jumlah komisaris independen maka pengawasan dari manajemen akan semakin ketat. Pengawasan yang semakin ketat akan

Vol. 12, No. 1, Januari 2021, Halaman 55-68 membuat manajemen bertindak lebih berhati-hati dalam mengambil keputusan dan transparan dalam menjalankan perusahaan sehingga dapat meminimalisasi praktik penghindaran pajak.

Hasil pada penelitian ini menunjukan bahwa komisaris independen tidak berpengaruh signifikan terhadap penghindaran pajak. Sejalan dengan penelitian Ni Koming (2017) dan Rizal (2016). Hasil yang menunjukkan bahwa komisaris independen yang tidak berpengaruh signifikan terhadap penghindaran pajak memiliki arti besar kecilnya komisaris independen tidak membuat praktik penghindaran pajak yang dilakukan oleh perusahaan tersebut dapat dihindari.

Adanya dewan komisaris diharapkan dapat mengurangi praktik penghindaran pajak, namun terdapat alasan yang menyebabkan dewan komisaris tidak berpengaruh terhadap penghindaran pajak, yaitu karena tidak semua anggota dewan komisaris independen dapat menunjukkan independensinya sehingga fungsi pengawasan tidak berjalan dengan efektif dan berdampak pada kurangnya pengawasan terhadap manajemen sehingga dewan komisaris independen tidak dapat menghalangi praktik penghindaran pajak.

\section{Pengaruh Komite Audit terhadap Penghindaran Pajak}

Hanum dan Zulaikha (2013) mengatakan bahwa komite audit sesuai fungsinya membantu dewan komisaris dalam melakukan pengawasan serta memberikan rekomendasi kepada manajemen dan dewan komisaris terhadap pengendalian yang telah berjalan sehingga 
dapat mencegah asimetri informasi. Semakin ketatnya pengawasan yang dilakukan pada manajemen perusahaan maka akan menghasilkan informasi yang lebih berkualitas dan kinerja yang lebih efektif. Berdasarkan hal tersebut, komite audit dengan semua wewenang yang dimilikinya diharapkan akan mencegah segala tindakan yang menyimpang terkait dengan laporan keuangan pada perusahaan. Hasil pada penelitian ini menunjukan bahwa komite audit tidak berpengaruh signifikan terhadap penghindaran pajak. Sejalan dengan penelitian Komang (2017) dan Fadhilah (2014). Hasil penelitian menunjukkan bahwa komite audit yang tidak berpengaruh signifikan terhadap penghindaran pajak memiliki arti besar kecilnya komite audit tidak membuat praktik penghindaran pajak yang dilakukan oleh perusahaan tersebut dapat dihindari.

Adanya komite audit diharapkan dapat mengurangi praktik penghindaran pajak, namun terdapat alasan yang menyebabkan komite audit tidak berpengaruh terhadap penghindaran pajak, yaitu karena kurang selektif perusahaan dalam merekrut komite audit sehingga kompetensi komite audit masih kurang memadai dalam menjalankan pekerjaannya, menjadikan komite audit kurang dapat membantu perusahaan dalam hal pelaporan keuangan, sehingga komite audit tidak bisa menjadi jaminan agar perusahaan terhindar dari penghindaran pajak.

\section{Pengaruh Kualitas Audit terhadap Penghindaran Pajak}

Vol. 12, No. 1, Januari 2021, Halaman 55-68
Audit merupakan elemen dalam corporate governance yang erat kaitannya dengan prinsip transparansi. Perusahaan publik semakin menuntut adanya transparansi atau keterbukaan informasi pada laporan keuangan. Laporan keuangan yang diaudit oleh auditor KAP The Big Four dipercaya lebih memiliki kualitas tinggi karena menampilkan nilai perusahaan yang sebenarnya. Oleh karena itu diduga perusahaan yang diaudit oleh auditor KAP The Big Four memiliki tingkat kecurangan yang lebih rendah dibandingkan dengan perusahaan yang diaudit oleh auditor KAP non The Big Four, dengan demikian tandatanda tindakan penghindaran akan dapat diketahui (Annisa, 2012).

Hasil pada penelitian ini menunjukan bahwa kualitas audit tidak berpengaruh signifikan terhadap penghindaran pajak. Sejalan dengan penelitian Fenny (2014) dan Dita (2018). Hasil penelitian menunjukkan bahwa kualitas audit yang tidak berpengaruh signifikan terhadap penghindaran pajak memiliki arti tidak ada perbedaan antara perusahaan yang diaudit oleh KAP Big 4 maupun non Big 4 terhadap penghindaran pajak

Alasan yang menyebabkan kualitas audit tidak berpengaruh terhadap penghindaran pajak karena ketika KAP mengaudit laporan keuangan sudah berpedoman pada standar pengendalian mutu kualitas audit yang telah ditetapkan oleh Dewan Standar Profesional Akuntan Publik Institut Akuntan Publik Indonesia (DSPAP IAPI) dan aturan etika akuntan publik yang ditetapkan oleh IAPI sehingga dalam pelaksanaannya sudah didasarkan 
pada aturan yang ada. Hal tersebut menyebabkan tidak adanya perbedaan antara perusahaan yang diaudit oleh KAP Big 4 maupun non Big 4.

\section{Pengaruh Profitabilitas, Kepemilikan} Institusional, Dewan Komisaris Independen, Komite Audit, dan Kualitas Audit Secara Simultan terhadap Penghindaran pajak

Profitabilitas

menggambarkan

kemampuan suatu perusahaan dalam menghasilkan laba selama periode tertentu. Apabila profit atau keuntungan sebuah perusahaan tinggi berarti beban pajak yang harus dibayarkan tinggi pula. Dengan melakukan penghindaran pajak perusahaan dapat meminimalkan pembayaran kasnya untuk pajak, sehingga perusahaan yang memiliki keuntungan yang tinggi cenderung akan melakukan peminimalan terhadap pembayaran pajaknya atau disebut telah melakukan praktik dari penghindaran pajak. Semakin tingginya profitabilitas sebuah perusahaan maka akan berdampak terhadap semakin tingginya penghindaran pajak yang dilakukan perusahaan tersebut.

Corporate Governance adalah suatu mekanisme yang mengatur dan mengendalikan perusahaan. Penerapan Corporate Governance yang baik dan benar akan menjaga keseimbangan antara pencapaian tujuan ekonomi dan masyarakat serta menjauhkan perusahaan dari pengelolaan yang buruk yang mengakibatkan perusahaan terkena masalah yang dapat mengurangi praktik penghindaran pajak.

Hasil pada penelitian ini menunjukan bahwa profitabilitas, kepemilikan institusional, dewan komisaris

Vol. 12, No. 1, Januari 2021, Halaman 55-68 independen, komite audit dan kualitas audit secara simultan berpengaruh signifikan terhadap penghindaran pajak. Sejalan dengan penelitian Komang (2016). Pada penelitian Komang (2016) Uji Statistik F memiliki tingkat signifikansi sebesar 0,005 yang lebih kecil dibandingkan tingkat signifikansi $\alpha$ sebesar 0,05 sehiingga dapat disimpulkan variabel independen dalam model penelitian Komang secara simultan berpengaruh terhadap variabel dependen.

\section{KESIMPULAN}

Berdasarkan hasil penelitian yang dilakukan pada perusahaan pertambangan yang terdaftar di BEI periode 2014-2018, maka dapat disimpulkan sebagai berikut: 1.Profitabilitas berpengaruh negatif dan signifikan terhadap penghindaran pajak.

2. Kepemilikan Institusional sebagai proksi dari Good Corporate Governance terbukti tidak berpengaruh signifikan terhadap penghindaran pajak.

3. Dewan Komisaris Independen sebagai proksi dari Good Corporate Governance tidak berpengaruh signifikan terhadap penghindaran pajak.

4. Komite Audit sebagai proksi dari Good Corporate Governance tidak berpengaruh signifikan terhadap penghindaran pajak.

5. Kualitas Audit sebagai proksi dari Good Corporate Governance tidak berpengaruh signifikan terhadap penghindaran pajak.

6. Profitabilitas, Kepemilikan Institusional, Dewan Komisaris Independen, Komite Audit, dan Kualitas Audit secara simultan berpengaruh secara signifikan terhadap penghindaran pajak.

\section{SARAN}


Adapun saran-saran yang dapat diberikan melalui hasil penelitian ini yaitu:

1. Bagi peneliti selanjutnya, diharapkan melakukan penelitian dengan periode rentan waktu yang lebih panjang agar lebih menangkap fenomena penghindaran pajak yang dilakukan perusahaan.

2. Bagi peneliti selanjutnya, diharapkan melakukan penelitian dengan sektor yang berbeda dan dengan jumlah sampel yang lebih banyak. Hal ini dimaksudkan agar hasil penelitian memiliki cakupan yang lebih luas dan mampu memperkuat hasil penelitian-penelitian yang telah dilakukan sebelumnya.

3. Bagi peneliti selanjutnya, diharapkan menambah variabel lain yang bisa diambil dari faktor eksternal maupun faktor internal perusahaan lainnya.

\section{DAFTAR PUSTAKA}

Adhelia, Dita. 2018. Pengaruh Good Corporate Governance terhadap Tax Avoidance (Studi Empiris pada Perusahaan Properti yang Terdaftar di BEI 2014-2017). Yogyakarta : Fakultas Ekonomi. Universitas Islam Indonesia Yogyakarta.

Annisa, Nuralifmida Ayu dan Lulus Kurniasih. 2012. Pengaruh Corporate Governance terhadap Tax Avoidance. Jurnal Akuntansi dan Auditing.

Cahyono, Deddy Dyas, Rita Andini, dan Kharis Raharjo. 2016. Pengaruh Komite SDKAA W3L Audit, Kepemilikan Institusional, Dewan Komisaris, Ukuran Perusahaan (Size), Leverage (DER), dan Profitabilitas (ROA) terhadap Tindakan Penghindaran Pajak (Tax Avoidance) pada Perusahan

Vol. 12, No. 1, Januari 2021, Halaman 55-68
Perbankan yang listing BEI Periode Tahun 2011-2013. Journal Of Accounting, Vol. 2, No.2.

Dewi, Ni Nyoman Kritiana dan I Ketut Jati. 2014. Pengaruh Karakter Eksekutif, Karakteristik Perusahaan, dan Dimensi Tata Kelola Perusahaan yang Baik pada Tax Avoidance di Bursa Efek Indonesi. E-Jurnal Akuntansi, Vol. 6.

Fadhilah, Rahmi. 2014. Pengaruh Good Corporate Governance terhadap Tax Avoidance. (Studi Empiris Pada Perusahaan Manufaktur yang Terdaftar di BEI 2009-2011). Fakultas Ekonomi Universitas Negeri Padang.

Ghozali, Imam. 2016. Aplikasi Analisis Multivariate dengan Program IBM SPSS 23. Semarang: Badan Penerbit Universitas Diponegoro.

Hamdi, Faouzi Mohamed, Mohamed Ali Zarai. 2013. "Perspectives of earnings management in Islamic Banking institusions". International Journal of Bussiness and Management Invention. Vol. 2, No. 9, Hal. 26-38.

Hanum, Hashemi Rodhian dan Zulaikha. 2013. Pengaruh Karakteristik Corporate Governance terhadap Effective Tax Rate. Diponegoro Journal of Accounting, Vol. 2.

Kurniasih, Tommy dan Maria Ratna Sari. 2013. Pengaruh Return on Assets, Leverage, Corporate Governance, Ukuran Perusahaan, dan Kompensasi Rugi Fiskal pada Tax 
Avoidance. Buletin Studi Ekonomi, Vol. 1, No. 18.

Maharani, I Gusti Ayu Cahya dan Ketut Alit Suardana. 2014. Pengaruh Corporate Governance, Profitabilitas, dan Karakteristik Eksekutif pada Tax Avoidance Perusahaan Manufaktur. E-Journal Akuntansi, Vol. 9, No. 2.

Praditasari, Ni Koming Ayu dan Putu Ery Setiawan. 2017. Pengaruh Good Corporate Governance, Ukuran Perusahaan, Leverage dan Profitabilitas pada Tax Avoidance. Jurnal Akuntansi, Vol.19, No.2,

Rizal, Noviansyah dan Fetri Setyo Liyundira. 2016. Pengaruh Tekanan Waktu dan Independensi terhadap Kualitas Audit. Jurnal Penelitian Ilmu Ekonomi

Subagiastra, Komang, Putu Edy Arizona, dan I Nyoman Kusuma Adnyana Mahaputra. 2016. Pengaruh Profitabilitas, Kepemilikan Keluarga, dan Good Corporate Governance terhadap Penghindaran Pajak. Jurnal Ilmiah Akuntansi, Vol. 1, No. 2, Hal. 167-193.

Utami, Nurindah Wahyu. 2013. Pengaruh Struktur Corporate Governance, size, Profitabailitas Perusahaan terhadap Tax Avoidance. (Studi Pada Perusahaan Pertambangan dan Manufaktur yang Terdaftar di BEI Tahun 2009-2011). Fakultas Ekonomi Universitas Negeri Padang.

Winata, Fenny. 2014. Pengaruh Corporate Governance terhadap Tax Avoidance pada Perusahaan yang terdaftar di Bursa Efek Indonesia
Tahun 2013. Tax and Accounting Review. Vol. 4, No.1.

Www.cnbcindonesia.com

www.edusaham.com

$\underline{\text { www.idx.co.id }}$ 